\title{
Job Satisfaction and Morale of Enlisted Personnel: Implications toward Counseling Provision in the Military Organization
}

\author{
Abu Yazid Abu Bakar \\ Noriah Mohd Ishak \\ Salleh Amat \\ Mohd Izwan Mahmud \\ Universiti Kebangsaan Malaysia \\ Email: yazid3338@ukm.edu.my
}

\section{Doi:10.5901/mjss.2015.v6n3s1p507}

\section{Abstract}

This research was conducted as an initial move to serve the purpose of studying the need to provide counseling services in the local military organizations. It was meant to study the correlation between job satisfaction and morale of enlisted personnel, whereby the theoretical framework of the research was developed based on Fredrik Herzberg's 2-factor theory of job satisfaction. A random sample of 50 active servicemen and servicewomen was selected from various locations throughout Malaysia to answer the survey instrument of the research. The quantitative data was descriptively analyzed and inferentially translated (using the Pearson Correlation and T-test method), resulting in two main findings: (a) There was a direct and significant correlation between job satisfaction and morale among research participants, and (b) there was a significant difference in job satisfaction and morale among research participants of differentage and serving duration. The focus of the discussion was directed on the findings and their implications toward the provision of counseling in military services as a whole.

Keywords: job satisfaction; morale; counseling; personnel; military organization;

\section{Introduction}

Greenberg and Baron (1997) defined job satisfaction as an individual's cognitive, affective and evaluative reactions toward his or her job, whereas Berry (1997) stated that job satisfaction as an individual's reaction towards his or her job experiences. It is believed that job satisfaction is a natural and stable instinct possessed by every individual that cut across time (Staw \& Ross, 1985; Gutek \& Winter, 1992). However, Frederik Herzberg, in his 2-factor job satisfaction theory, believed that a combination of motivational factors (comprised of elements such as organizational policies/administration, control/coordination, emolument/benefits, and workplace communication/environment) and hygiene factors (job perception, individual achievement/performance, recognition, job responsibility, and career development) became the critical determinants of an individual's satisfaction toward his or her job (Hunt \& Hill, 1976; O'Connor, Bronner \& Delaney, 1996). A study by Syptak, Marsland and Ulmer (1999) depicted that employees with high job satifaction had tendencies to be more productive, creative and committed toward their jobs and employers. On the contrary, numerous research works concerning organizational job satisfaction had found its' correlational association with workplace problems such as absenteeism, stress, burnout, turnover, and overall well-being of personnel (Ybema, Smulders \& Bongers, 2010; Hassell, Archbold \& Stichman, 2010; Doest, Maes, Gebhardt \& Koelewijn, 2006; Chiu \& Chen, 2005).

Morale, on the other hand, has generally being defined by Kellett (1982) as the spirit or confidence level of an individual or a group of people, pillared by three vital elements namely the self-satisfaction, self-motivation, and group concern. Studies conducted on individual's job morale had found out that it is built on elements such as discipline, leadership, self pride, job's suitability, religion, ideology, and health (Baynes, 1967). Another general definition of morale stated that it is a psychological state shared by members of a group that consists of general feelings of satisfaction with conditions that have impact on the group and strong motivation to accomplish group objectives despite obstacles or adversity (Motowildo \& Borman, 1977). However, in the military perspective, morale is defined more than just a satisfaction, motivation or group cohesiveness; in fact, it is considered as a complex construct that includes a vast array 
of attitudinal, motivational, and social predispositions and it is undeniably a very important determinant of personnel and unit effectiveness as a whole (Motowildo \& Borman, 1978). On a similar note, a study conducted by Leong (1992) revealed that morale of local military officers - defined in terms of their tendencies to remain in the service - was influenced by the such motivational and hygienic factors as being described by Herzberg's 2-factor theory of job satisfaction.

With the existence of various human resource management issues; for instance; the increase of turnover rate due to stress and boredom, the need to establish a dedicated counseling services to tackle such issues are highly in demand in many organizations including the military. Hence, this study was formulated to gather initial data to justify the provision of counseling services in military establishments, particularly in the training centers. Theoretically, the research framework (as being illustrated in Figure 1) is a conceptual combination of job satisfaction (based on theory proposed by Herzberg) and morale constructs described by Motowildo and Borman (1977).

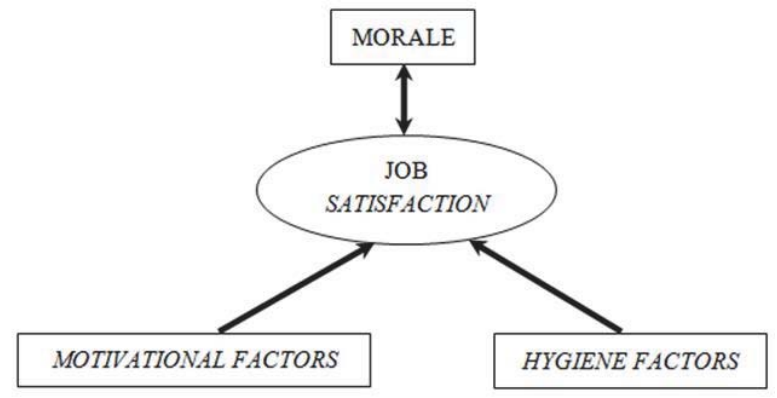

Figure 1. Research Theoretical Framework

Objectively, the study was specifically designed to answer these five research questions:

a) Is there a correlation between motivational factor of job satisfaction and morale among respondents?

b) Is there a correlation between hygiene factor of job satisfaction and morale among respondents?

c) Is there a correlation between job satisfaction (combination of motivational and hygiene factors) and morale among respondents?

d) Is there a difference in job satisfaction among respondents varying in age and service duration?

e) Is there a difference in morale among respondents varying in age and service duration?

\section{Research Methodology}

This survey research adopted a cross-sectional design in which data was collected only once throughout the whole duration of the study (Cozby, 1993). Fifty subjects were randomly sampled from five military bases (located in Perak, Pahang, Johor, Sabah, and the Federal Territory of Kuala Lumpur) throughout Malaysia. A survey questionnaire used in this research had been developed from the adaptation of several instruments such as the Job Description Index (JDI), the Minnesota Satisfaction Questionnaire (MSQ) and the Pay Satisfaction Questionnaire (PSQ). The reliability analysis using Statistical Package for the Social Sciences (SPSS) software version 16.0 revealed that this 70-item instrument had an Alpha Cronbach value of $0.81(\alpha=0.81)$. All of the items were segregated into three categories namely:

a) Section A - 5 items concerning the demographic information of the subjects

b) Section B - 50 items of Herzberg's job satisfaction factors (25 items on motivational factor and 25 items on hygiene factor) on a 5-point Likert Scale

c) Section C - 15 items (3 of them were negative items) on personnel's morale towards current job

The administrative process of the instrument was done by appointing a representative in every location, whereby the questionnaires were distributed whether by hand or by electronic mail (e-mail). The appointed representatives were responsible to ensure that all the questionnaires were completed and returned within the stipulated time frame.

\section{Results and Findings}

Demographically, the sample comprised of 86 percent male and 14 percent female respondents, which reflected the current ratio of 1 servicewoman to 7 servicemen in the whole military force of the nation. Age wise, there was an equal 
balance between personnel in the 29 years old and below age group, and the 30 years old and above age group. Furthermore, more than 50 percent of the respondents had served less than 9 years. Table 1 depicted the demographic data of the research's respondents.

Table 1. Demographic Data of Research Participants

\begin{tabular}{|ccc|}
\hline & Total Number $(\mathrm{N})$ & Percentage $(\%)$ \\
\hline Gender & 43 & \\
Male & 7 & 86.00 \\
Female & 25 & 14.00 \\
Age Group & 25 & 50.00 \\
29 years old and below & & 50.00 \\
30 years old and above & 27 & \\
& 23 & 54.00 \\
Duration of Service & 23.00 \\
\hline years and below & & \\
\hline More than 10 years & &
\end{tabular}

Table 2 revealed the descriptive statistics of the research's variables in which, mean for motivational factor items is 83.14 whereas mean for hygiene factor items is 81.82. Thus, mean for job satisfaction (a combination of motivational and hygiene factors) is 164.96 , while mean for morale is 51.74 .

Table 2. Descriptive Statistics of Research Variables

\begin{tabular}{|cccc|}
\hline Variables & N & Mean & Std. Dev. \\
\hline Motivational Factor & 50 & 83.14 & 13.12 \\
Hygiene factor & 50 & 81.82 & 16.71 \\
Job Satisfaction & 50 & 164.96 & 28.69 \\
Morale & 50 & 51.74 & 5.82 \\
\hline
\end{tabular}

Table 3 showed the moderately significant correlation $(r=0.48, p<0.01)$ between motivational factor items and morale of the respondents. The item scores were evenly scattered, which reflects the direct correlational relationship as being demonstrated in Figure 2.

Table 3. Pearson Correlation between Motivational Factors and Morale

\begin{tabular}{|lcc|}
\hline & MOTIVATIONAL FACTORS & MORALE \\
\hline MOTIVATIONAL Pearson Correlation & 1 & $0.48^{\star \star}$ \\
FACTORS Sig. (2-tail) &.$\cdot 00$ \\
N & 50 & 50 \\
MORALE Pearson Correlation & $0.48^{\star \star}$ & 1 \\
Sig. (2-tail) & .00 &. \\
$\mathrm{~N}$ & 50 & 50 \\
\hline
\end{tabular}

** Significant at $p$ values $<0.01$

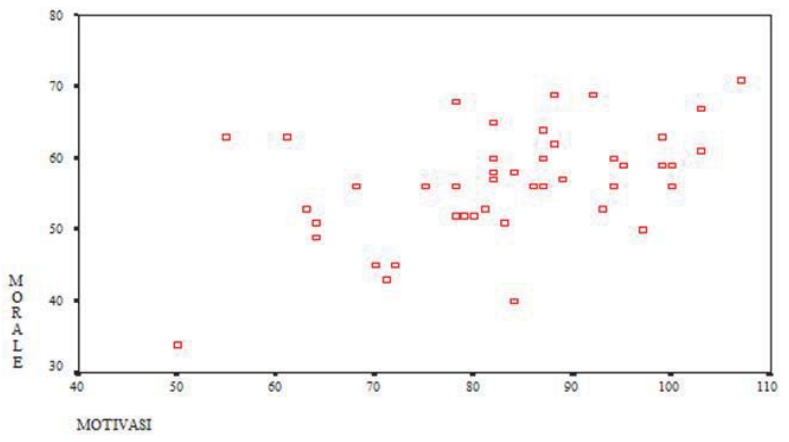

Figure 2. Motivational Factor and Morale Scores Plot 
Similarly, Table 4 showed the moderately significant correlation $(r=0.51, p<0.01)$ between hygiene factor items and morale of the respondents. The item scores were evenly scattered, which reflects the direct correlational relationship as being demonstrated in Figure 3.

Table 4. Pearson Correlation between Hygiene Factors and Morale

\begin{tabular}{|lcc|}
\hline & HYGIENE FACTORS & MORALE \\
\hline HYGIENE Pearson Correlation & 1 & $0.51^{* *}$ \\
FACTORS Sig. (2-tail) &. & .00 \\
N & 50 & 50 \\
MORALE Pearson Correlation & $0.51^{* *}$ & 1 \\
Sig. (2-tail) & .00 &. \\
N & 50 & 50 \\
\hline
\end{tabular}

** Significant at $p$ values $<0.01$

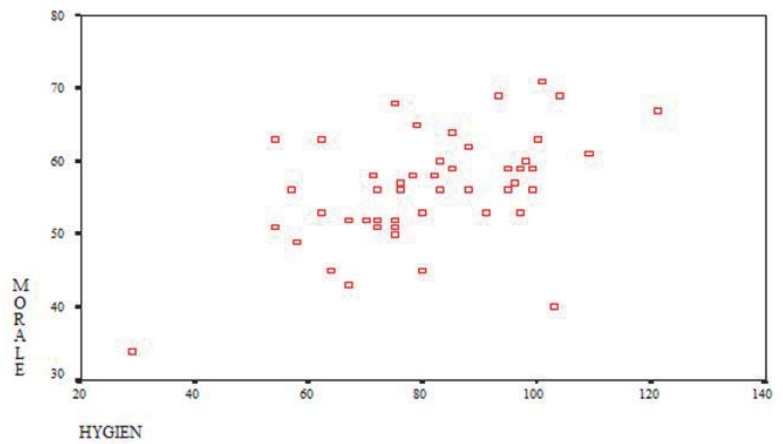

Figure 3. Hygiene Factor and Morale Scores Plot

Since job satisfaction in this study is defined as the combination of motivational and hygiene factors, it was found to have the same moderately significant correlation $(r=0.52, p<0.01)$ with morale of the respondents as being displayed in Table 5. The item scores were also evenly scattered, which reflects the direct correlational relationship as being demonstrated in Figure 4.

Table 5. Pearson Correlation between Job Satisfaction and Morale

\begin{tabular}{|lcc|}
\hline & JOB SATISFACTION & MORALE \\
\hline JOB SATISFACTION Pearson Correlation & 1 & $0.52^{\star \star}$ \\
Sig. (2-tail) &. & .00 \\
N & 50 & 50 \\
MORALE Pearson Correlation & $0.52^{\star *}$ & 1 \\
Sig. (2-tail) & .00 &. \\
N & 50 & 50 \\
\hline
\end{tabular}

** Significant at $p$ values $<0.01$

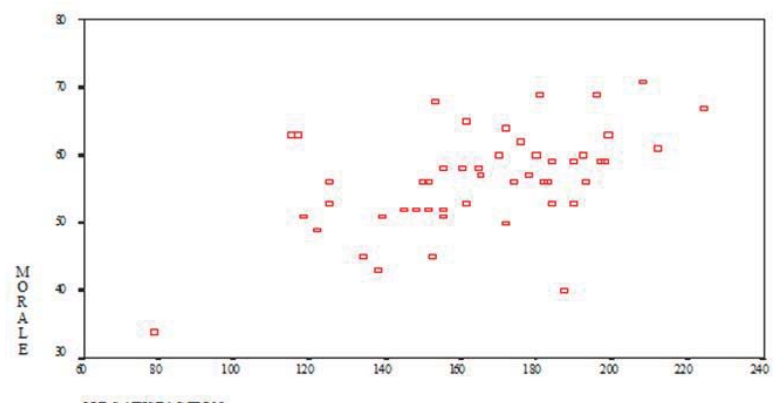

Figure 4. Job Satisfaction and Morale Scores Plot 
Another result revealed that there was a significant difference in job satisfaction among personnel varies in age. Concomittantly, job satisfaction among personnel ages 30 years old and above was higher as compared to those below 29 years old (refer Table 6). Similarly, as illustrated in Table 7, job satisfaction among personnel who had longer serving terms was higher than those who were considered juniors.

Table 6. T-test Result on Participants' Job Satisfaction Based on Age

\begin{tabular}{|c|c|c|c|c|c|c|}
\hline & $\mathrm{N}$ & Mean & Std. Deviation & $\mathrm{t}$ & $\mathrm{df}$ & Sig \\
\hline $\begin{array}{l}\text { Job satisfaction of personnel aged } 29 \text { years old and below } \\
\text { Job satisfaction of personnel aged } 30 \text { years old and above }\end{array}$ & $\begin{array}{l}25 \\
25\end{array}$ & $\begin{array}{l}158.72 \\
170.20\end{array}$ & $\begin{array}{l}31.34 \\
25.79\end{array}$ & -1.41 & $48^{*}$ & .00 \\
\hline
\end{tabular}
*k<0.05

Table 7. T-test Result on Participants' Job Satisfaction Based on Service Duration

\begin{tabular}{|ccccccc|}
\hline & $\mathrm{N}$ & Mean & Std. Deviation & $\mathrm{t}$ & $\mathrm{df}$ & Sig \\
\hline Job satisfaction of personnel who served less than 9 years & 27 & 159.41 & 30.49 & \multirow{2}{*}{-1.35} & \multirow{2}{*}{$48^{*}$} & \multirow{2}{*}{.00} \\
\hline Job satisfaction of personnel who served more than 10 years & 23 & 170.39 & 26.54 & & &
\end{tabular}

Another finding revealed that there was a significant difference in morale among participants varies in age, in which morale among personnel ages 30 years old and above was found to be higher as compared to those below 29 years of age (refer Table 8). Table 9, on the same note, showed that morale among personnel who served longer is higher, in comparison to the junior ones.

Table 8. T-test Result on Participants' Morale Based on Age

\begin{tabular}{|lrrrrrr|}
\hline & $\mathrm{N}$ & Mean & Std. Deviation & $\mathrm{t}$ & $\mathrm{df}$ & Sig \\
\hline Morale of personnel aged 29 years old and below & 25 & 54.24 & 7.14 & \multirow{2}{*}{-1.98} & \multirow{2}{*}{$48^{*}$} & \multirow{2}{*}{.00} \\
\hline Morale of personnel aged 30 years old and above & 25 & 58.28 & 7.27 & & & \\
*k<0.05
\end{tabular}

Table 9. T-test Result on Participants' Morale Based on Service Duration

\begin{tabular}{|lllllll|}
\hline & $\mathrm{N}$ & Mean & Std. Deviation & $\mathrm{t}$ & $\mathrm{df}$ & Sig \\
\hline Morale of personnel who served less than 9 years & 27 & 54.81 & 7.35 & -1.35 & $48^{*}$ & .00 \\
Morale of personnel who served more than 10 years & 23 & 57.96 & 7.28 & & & \\
\hline
\end{tabular}

${ }^{*} k<0.05$

\section{Discussion and Conclusion}

All null hypotheses that correspond to the five research questions had been rejected by the findings. Cohen (1977) stated that $r$ value more than 0.30 demonstrates a moderate correlation whereas Cozby (1993) believed that $r$ value in the range of 0.50 to 0.69 has the same correlational strength. Since statistics in Table 3, 4 and 5 revealed the $r$ values that fall in this range (0.48, 0.51 and 0.52 respectively), a conclusion can be drawn that job satisfaction - whether as motivational/hygiene dimension or holistically a whole - is significantly correlated to morale, in a moderate strength relationship; thus, rejects the null hypotheses that correspond to the first three research questions. However, the researchers believed that these moderately significant correlations occured particularly due to the small number of respondents $(n=50)$, and the increase of respondents would possibly increased the strength of the correlations. On a similar note, statistics presented in Table 6, 7, 8 and 9 have clearly proven that there were significant differences in job satisfaction and morale among respondents varying in age and service duration; hence, reject the null hypotheses for the remaining two research questions. A small differences in mean and small $t$ values in these statistical data were also caused probably by the small number of respondents $(n=50)$, which in turn might weaken its' inferential power. Therefore, for future research, the increase of sample size, as suggested by Jackson (2003) is recommended, because it might increase the inferential power of the data. 
In other words, a direct and significant correlation between job satisfaction and morale among research respondents indicated that all factors pertinent to enhancing the two variables in the workplace should be seriously considered by the management of military organizations. As Motowildo and Borman (1978) classified in their study that morale of military servicemen is closely associated with their satisfaction with the job itself, pay, supervision, co-workers, promotions, community, and communications, it is clear that there are lots of factors to be monitored in order to keep the servicemen motivated. Moreover, the results of the study indicated that the existence of generation gap effect on job satisfaction and morale of the personnel; thus, the management should realize that the younger generation need to be motivated in different approaches to keep them away from getting involved in any unbecoming activities.

Hence, these two main findings justified the necessity for military institutions to provide counseling services, particularly in the organizational and career development/growth dimensions. Specifically, the provision of organizational counseling activities such as stress management talks, team building programs, and conflict resolution/anger management courses will provide the personnel with necessary humanistic skills that can be used to cope with daily workplace problems. Moreover, in terms of upholding its' personnel job satisfaction and morale, the introduction of career development initiatives such as appropriate incentive scheme and proper career progress, would be some good moves that might be considered by the top management officials. Furthermore, counseling sessions should also be provided to all personnel, be it individual, group or family, to help ease any burning issues that might arise while they were carrying out their tasks and responsibilities. These sessions will not only allow them to share and get help to solve their problems, but also provide them with the opportunity to safeguard their overall satisfaction and morale.

In a nutshell, by implementing all of these counseling strategies in the rigid and highly structured setting of military services, it will be considered as a revolutionary effort in strengthening the nation as a whole. Military should not be viewed as a closed and isolated community anymore, it should rather be seen as an opened entity which is willing to adopt a new approach to enhance the well-being of the personnel, and organizational counseling would be a very good start.

\section{References}

Baynes, J. (1967). Morale: A study of men and courage. New York, NY: Praeger.

Berry, L.M. (1997). Psychology at work. San Francisco, CA: McGraw Hill.

Chiu, S.F. \& Chen, H.L. (2005). Relationship between job characteristics and organizational citizenship behavior: The mediational role of job satisfaction. Social Behavior and Personality, 33(6): 523-540.

Cohen, J. (1977). Statistical power analysis for the behavioral sciences. New York, NY: Academic Press.

Cozby, P.C. (1993). Methods in behavioral research. $5^{\text {th }}$ Ed. California: Mayfield Publishing Company.

Doest, L.T., Maes, S., Gebhardt, W.A. \& Koelewijn, H. (2006). Personal goal facilitation through work: Implications for employee satisfaction and well-being. Applied Psychology: An International Review, 55(2): 192-219.

Gutek, B.A., \& Winter, S.J. (1992). Consistency of job satisfaction across situations: Fact or framing artifact? Journal of Vocational Behavior, 41: 61-78.

Greenberg, J., \& Baron, R.A. (1997). Behavior in organizations: Understanding and managing the human side of work. $6^{\text {th }}$ Ed. Upper Saddle River, NJ: Prentice-Hall.

Hassell, K.D., Archbold, C.A. \& Stichman, A.J. (2011). Comparing the workplace experiences of male and female police officers: Examining workplace problems, stress, job satisfaction and consideration of career change. International Journal of Police Science and Management, 13(1): 37-53.

Hunt, J.G., \& Hill, J.W. (1976). The new look in motivation theory for organizational research. In the Associates, Office of Military Leadership, United States Military Academy (Eds.), A study of organizational leadership (pp. 476-490). Harrisburg, PA: Stackpole Books.

Jackson, S.L. (2003). Research methods and statistics: A critical thinking approach. California: Thomson Wadsworth.

Kellett, A. (1982). Combat motivation. Boston, MA: Nijhoff Publishing.

Leong, L.P. (1992). Pemilihan dan penerusan kerjaya pegawai ATM. Sumber Markas ATM, Julai: 42-51.

Motowildo, S.J. \& Borman, W.C. (1977). Behaviorally anchored scales for measuring morale in military units. Journal of Applied Psychology, 62(2): 177-183.

Motowildo, S.J. \& Borman, W.C. (1978). Relationships between military morale, motivation, satisfaction, and unit effectiveness. Journal of Applied Psychology, 63(1): 47-52.

O'Connor, B.N., Bronner, M., \& Delaney, C. (1996). Training for organizations. Cincinnati, OH: South-Western Educational Publishing.

Staw, B.M., \& Ross, J. (1985). Stability in the midsts of change: A dispositional approach to job attitudes. Journal of Applied Psychology, 70: 56-77.

Syptak, J.M., Marsland, D.W., \& Ulmer D. (1999). Job satisfacion: Putting theory into practice. Family Practice Management, 6(9): 26-30.

Ybema, J.F., Smulders, P.G.W., \& Bongers P.M. (2010). Antecedents and consequences of employee absenteeism: A longitudinal perspective on the role of job satisfaction and burnout. European Journal of Work and Organizational Psychology, 19(1): 102-124. 